\title{
ERRATUM TO: EXPRESSION CHANGES IN FATTY ACID METABOLIC PROCESSRELATED GENES IN PORCINE OOCYTES DURING IN VITRO MATURATION
}

\section{Erratum to:}

Expression changes in fatty acid metabolic processrelated genes in porcine oocytes during in vitro maturation

Joanna Budna, Piotr Celichowski, Artur Bryja, Michal Jeseta, Maurycy Jankowski, Dorota Bukowska, Paweł Antosik, Andrzej Nowicki, Klaus P. Brüssow, Małgorzata Bruska, Michał Nowicki, Maciej Zabel, Bartosz Kempisty

Medical Journal of Cell Biology 2018, Volume 6, Issue 2, pages 48-54 (DOI: doi.org/10.2478/ acb-2018-0009)

The number of supporting grant was incorrect. For the reader's convenience, the corrected ACKNOWLEDGEMENTS chapter appears below:

ACKNOWLEDGEMENTS

Publication of this article was made possible by grant number UMO-2012/07/N/NZ5/00069 from Polish National Centre of Science 